\title{
Economists Need People Too: A Tribute to John Virgo
}

\author{
Jannett Highfill
}

Published online: 19 July 2013

(C) International Atlantic Economic Society 2013

\begin{abstract}
A Tribute to John Virgo
\end{abstract}
Keyword Tribute

John Virgo was a man with a vision, probably several of them in fact, but the one that affected me most directly was his passion for bringing economists together for a particular kind of fruitful conversation. Malcolm Gladwell, in The Tipping Point (2000), describes the process by which ideas spread as well as the rare people with the special gifts required to make it happen. One type of these he called the "connector": a person who knows many people and makes a practice of introducing them to each other. John Virgo was a connector. He chose many formal and informal ways to make those connections, but the International Atlantic Economic Society, with its two journals, the Atlantic Economic Journal and the International Advances in Economic Research, must certainly be counted as one of the key components of his legacy. I am one of many economists who owe John a debt of gratitude for helping me connect with ideas and people at certain turning points in my life as an economist.

As a global economist, I appreciated his unflagging efforts to bring economists from both sides of the Atlantic together, not to mention those from around the world. I have enjoyed and benefited from those sessions, plenary speeches, and informal conversations. In a different way, I have relied particularly on papers John published in his journals. A couple of years ago, some coauthors and I wrote a survey on various aspects of the foreign direct investment (FDI) literature. One of our goals was to write a complementary piece to Bruce Blonigen's FDI 2005 survey in the AEJ. I've incorporated FDI pieces from both journals into my courses. My colleague Kevin O'Brien and I have drawn repeatedly on the AEJ contributions to the auction literature, especially the empirical testing of auction theory predictions, using internet auction data. I'd like to do more with the sports literature, perhaps by following up an ancient baseball paper my old friend and collaborator William Weber and I gave at an IAES conference in Athens in 2001.

\footnotetext{
J. Highfill $(\square)$

Bradley University, Peoria, IL, USA

e-mail: highfill@bradley.edu
} 
I'll end with a personal story. Early in my career, Bill Weber and I met John the way I'd guess many people have, at the registration table at an IAES conference in Plymouth Massachusetts. As it happened, there was a Nobel Prize winner in the audience for our paper - the first time that had happened in our experience and perhaps the last, for all I know. It was many years before I knew John well enough to tell him the story. When I did, he couldn't have been more kind.

\section{Last Session Sonnet}

My friend Bill Weber sketched out isoquants and budget constraints on a marker board just like a basketball coach would show a new pick and roll play to his players. Bill Vickrey, yes that one, sat beside me on the back row doing the Sunday cross word puzzle (nodding off from time to time) woke up on the hour, cut off the pompous discussant mid-word, and said our work would be fine once the discount rate was straightened out. I told John Virgo that story midconversation years later, learned he could say "no kidding" without saying a word, that wry smile, a certain tilt of his head. 